\title{
Bycatch reduction device conserves diamondback terrapin without affecting catch of blue crab
}

\author{
Megan A. Rook $^{1, *}$, Romuald N. Lipcius ${ }^{2}$, Bret M. Bronner ${ }^{1}$, Randolph M. Chambers ${ }^{1}$ \\ ${ }^{1}$ Department of Biology and Keck Environmental Lab, The College of William and Mary, Williamsburg, Virginia 23187, USA \\ ${ }^{2}$ Virginia Institute of Marine Science, The College of William and Mary, Gloucester Point, Virginia 23062, USA
}

\begin{abstract}
Bycatch mortality of non-target species in fisheries is a major threat to the conservation and restoration of marine and estuarine species. Attempts to reduce bycatch by fitting fishing gear with excluder devices have typically been met with resistance due to reductions in catch of target species. We examined the possibility that conservation and fishery goals could be met simultaneously. In lower Chesapeake Bay, we tested a mechanism for reducing bycatch of diamondback terrapin Malaclemys terrapin in blue-crab traps without affecting crab catch. Over 23 sampling dates during summer 2008, we compared terrapin captures at 2 shallow-water sites typical of recreational crabbing, using 10 paired sets of an un-baited trap fitted with bycatch reduction devices (BRDs) and a trap without BRDs at each site on each date. In a separate experiment, traps were baited and fished 4 times during the summer, when we recorded number, size, and condition of captured crabs. Of 48 terrapin captures in crab traps, only 2 were from traps fitted with BRDs. Crab catch (number, size, and biomass) was equivalent between traps with and without BRDs. Because BRDs are effective in excluding all but the smallest terrapins from entering crab traps and had no effect on crab catch, BRDs are recommended for all recreational crab traps at this time and should be seriously considered for commercial traps throughout shallow estuarine waters. Combined with bycatch reduction policies in other North American estuaries, a comprehensive and effective strategy for the conservation of diamondback terrapin threatened by fisheries is emerging.
\end{abstract}

KEY WORDS: Bycatch reduction device $\cdot$ Diamondback terrapin $\cdot$ Blue crab $\cdot$ Trap mortality Resale or republication not permitted without written consent of the publisher

\section{INTRODUCTION}

A major threat to organisms in coastal environments arises from the overexploitation of non-target species as intentional catch or unintentional take as bycatch (Lewison et al. 2004). Significant bycatch can result in rapid depletion of the non-target population or a demographic shift in body size, sex ratio, and age structure, all of which may lead to severe population depletion. Frequently, the outcome of severe bycatch is a smaller size and younger age at maturity. Smaller body size may mean a decrease in fecundity (Conover \& Munch 2002, Lipcius \& Stockhausen 2002) or decreased fertilization rates (Jamieson et al. 1998). At worst, local extinctions result.

Attempts to reduce bycatch can be met with resistance from the fishing community. Conservation goals are often in direct conflict with proximate fisheries goals (Heppell et al. 2004), and gear modifications are frequently perceived to be detrimental to catch of target species in the short-term, though few rigorous studies have actually examined the effects of gear modifications on catch. However, as Preikshot \& Pauly (2004, p. 185) state, 'Sustainable management of fisheries cannot be achieved without an acceptance that the long-term goals of fisheries management are the same as those of environmental conservation.' For conservation to be successful and for fisheries to persist, both conservation measures and fisheries management need to move away from a single-species focus and move toward an integrated ecosystem- and economics-based approach.

A candidate model system in which to test this proactive approach is that of the interaction of the dia- 
mondback terrapin and the blue crab Callinectes sapidus fishery. The diamondback terrapin Malaclemys terrapin is the only turtle in North America to inhabit estuarine environments exclusively (Ernst et al. 1994). Terrapins, while generally considered Kselected species living in excess of $40 \mathrm{yr}$, become sexually mature between the ages of 6 and $13 \mathrm{yr}$, yet exhibit a reproductive strategy in which many eggs are produced but only a few survive to adulthood (Hildebrand 1932, Roosenburg \& Green 2000, Tucker et al. 2001, M. A. Rook pers. obs.). Terrapins are potentially keystone predators in estuarine ecosystems, feeding on prey such as crabs, mussels, salt marsh periwinkles, barnacles, and clams (Tucker et al. 1995, Silliman \& Bertness 2002). The most abundant and common prey is the salt marsh periwinkle Littoraria irrorata, which comprises as much as $79 \%$ of the total food intake by mass in some areas (Coker 1920, Tucker et al. 1995). When unchecked by predators, L. irrorata can defoliate a marsh in as little as 8 mo (Silliman \& Bertness 2002). Adult terrapins in turn are prey of bald eagles (Clark 1982 ) and may be eaten by toadfish and crabs (Cecala et al. 2008).

Terrapins have a long history of overexploitation, having been hunted to commercial extinction in the early 1900s (Coker 1906). Soon thereafter, a captive breeding program, a moratorium on terrapin harvest, and a dwindling demand for terrapin meat helped some populations recover (Yearicks et al. 1981, Garber 1990). By the late 20th century, populations had been making a steady comeback until numerous anthropogenic changes to coastal environments combined to threaten populations anew (Butler et al. 2006).

Among all threats to terrapins, mortality in crab traps is the most serious in North America (Butler et al. 2006). In the USA, the terrapin's range is restricted to the Atlantic and Gulf coast tidal marshes from Massachusetts to Texas, including the Florida Keys. The terrapin also inhabits estuaries of Bermuda (Davenport et al. 2005, Bonin 2006, Parham et al. 2008). Throughout much of this range, estuarine waters are replete with blue-crab traps. Terrapins enter baited or un-baited traps where they drown or die of exposure if not released within a few hours of entrapment. Crab traps selectively capture immature males and females, as well as mature males, which are smaller than mature females (Roosenburg et al. 1997, Wood 1997, M. E. Wolak unpubl. data). Mature females are too large to fit through the standard gape in a crab trap, while very young terrapins are too small to become entrapped.

Selective removal of all but the youngest males and pre-reproductive females has the potential to shift terrapin population dynamics (Dorcas et al. 2007) and cause rapid local extinctions. Mortality in commercial crab traps can remove anywhere from 15 to $78 \%$ of a population in 1 yr (Roosenburg et al. 1997) and reduce lifespan below the age at maturity (Tucker et al. 2001). Decreases in population size as well as demographic shifts in size structure, age structure, and sex ratio may also occur (Bishop 1983, Wood 1997, Hoyle \& Gibbons 2000). As a result, in the USA the diamondback terrapin is listed as 'endangered' in 1 state (Rhode Island), 'threatened' in 1 state (Massachusetts), and 'vulnerable' or 'imperiled' in 8 states (North Carolina, Louisiana, Alabama, Mississippi, Georgia, Texas, Connecticut, and New York).

The threat from crab traps differs by use. Standard commercial crab traps are constantly submerged and typically checked daily. The constant submersion poses a major threat but drowning is limited due to the high frequency with which the traps are checked and because commercial traps are most often placed in deeper water outside of the terrapin's normal home range (Roosenburg et al. 2008). The predominant threat from commercial traps comes in the form of ghost traps, which are traps that have been lost or abandoned and remain in the estuary, continuously trapping all animals that enter. For example, Bishop (1983) found 1 ghost trap with 28 dead terrapins and Roosenburg (1991) found 1 trap with 49 terrapin shells, among other animal remains.

Recreational crab traps are identical in structure to commercial traps but are used for private, recreational crabbing. Though fewer in number, recreational traps potentially pose a more serious threat because private crabbers tend to place traps in shallow-water habitats where terrapins are more common and traps are checked less frequently (Hoyle \& Gibbons 2000).

In upper Chesapeake Bay and in Delaware Bay, bycatch reduction devices (BRDs) are required on all recreational crab traps, while in Delaware Bay, BRDs are required on any trap set in tidal creeks $<50 \mathrm{~m}$ wide at mean low water (http://dnr.maryland.gov, www.fw. delaware.gov, www.state.nj.us). Several studies have examined the effects of BRDs on reducing the terrapin bycatch but few have examined the effect of BRDs on the crab catch. The effects of BRDs on terrapin bycatch and crab catch vary by site and results from 1 site cannot be applied to other localities (Wood 1997, Roosenburg \& Green 2000, Butler \& Heinrich 2007). In addition, given the extent and commercial importance of the blue-crab fisheries throughout the Atlantic and Gulf of Mexico coasts (e.g. Lipcius \& Stockhausen 2002), the threat from crab traps is not likely to decrease in the near future. Consequently, we sought to (1) determine the effects of BRDs in crab traps on terrapin mortality and blue-crab catch in lower Chesapeake Bay, and (2) devise a conservation strategy that could be implemented with the least resistance, as a model for a win-win strategy in marine conservation. 


\section{MATERIALS AND METHODS}

Study sites. The experiments were conducted at Felgate's Creek, part of the Yorktown Naval Weapons Station on the York River, Virginia, and at an unnamed creek in Fort Eustis on the James River, Virginia, USA (Fig. 1). Felgate's Creek has a tidal range of $1.3 \mathrm{~m}$. At low tide, all but the very center of the main channel is a mudflat. The part of the creek used as our sampling site was surrounded by a healthy tidal marsh composed mainly of Spartina alterniflora, grading upland into pinedominated forest. The marsh supports abundant stocks of salt marsh periwinkles Littoraria irrorata, fiddler crabs Uca spp., and mussels Geukensia demissa, among other potential terrapin prey species (M. A. Rook pers. obs.).

The Fort Eustis site includes a network of tidal creeks that had never been sampled for terrapins. The experimental creek was surrounded by brackish marsh dominated by Spartina alterniflora, S. patens, Juncus roemarianus, and Phragmites australis. Standard terrapin prey such as periwinkles and blue crabs were abundant, but no terrapins and only freshwater mud turtles Kinosternon subrubrum and pond sliders Trachemys spp. were observed. As a result, the Fort Eustis site was used to study the effect of BRDs on crab catch but not on terrapin bycatch.

Sampling design. During summer 2008, 10 pairs of crab traps were placed throughout each of the 2 creeks. Each pair consisted of 1 crab trap without BRDs ('non-BRD trap') and 1 crab trap fitted with a $4.5 \times$ $12 \mathrm{~cm}$ plastic BRD (Fig. 2) on each of its 4 entrances ('BRD trap'). Trap pairs were placed side by side in the entrances of shallow-water $(<2 \mathrm{~m})$ marsh creeks, mimicking the intersection of terrapin habitat and recreational crabbing sites. Blue crabs were sampled for a single trapping interval once a week for $4 \mathrm{wk}$. Traps were baited at the beginning of the week and checked after $48 \mathrm{~h}$. The numbers of legal-size and sublegal-size

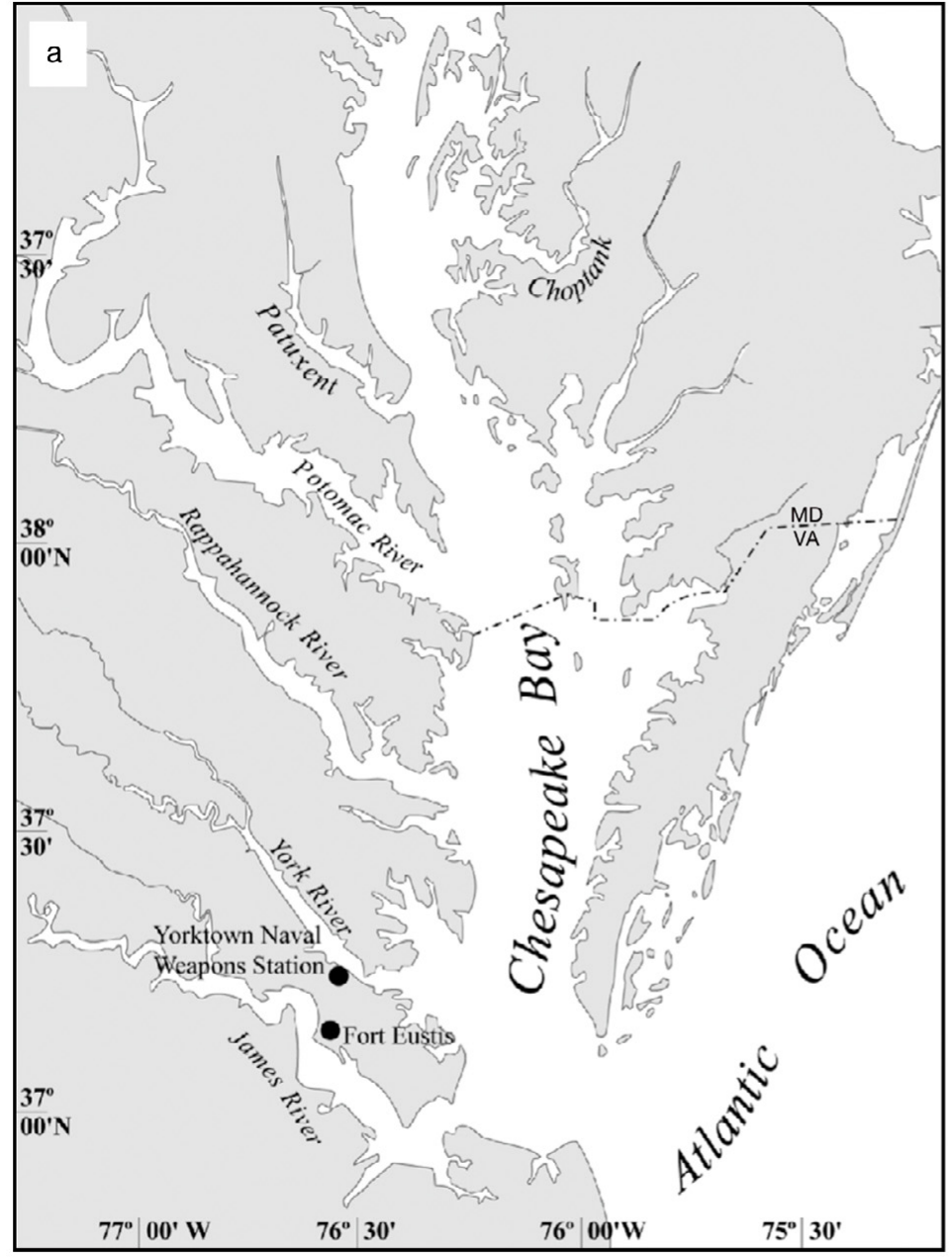

Fig. 1. (a) Study sites in lower Chesapeake Bay. (b) Felgate's Creek in the Yorktown Naval Weapons Station. (c) Fort Eustis. Each yellow point represents 1 crab trap
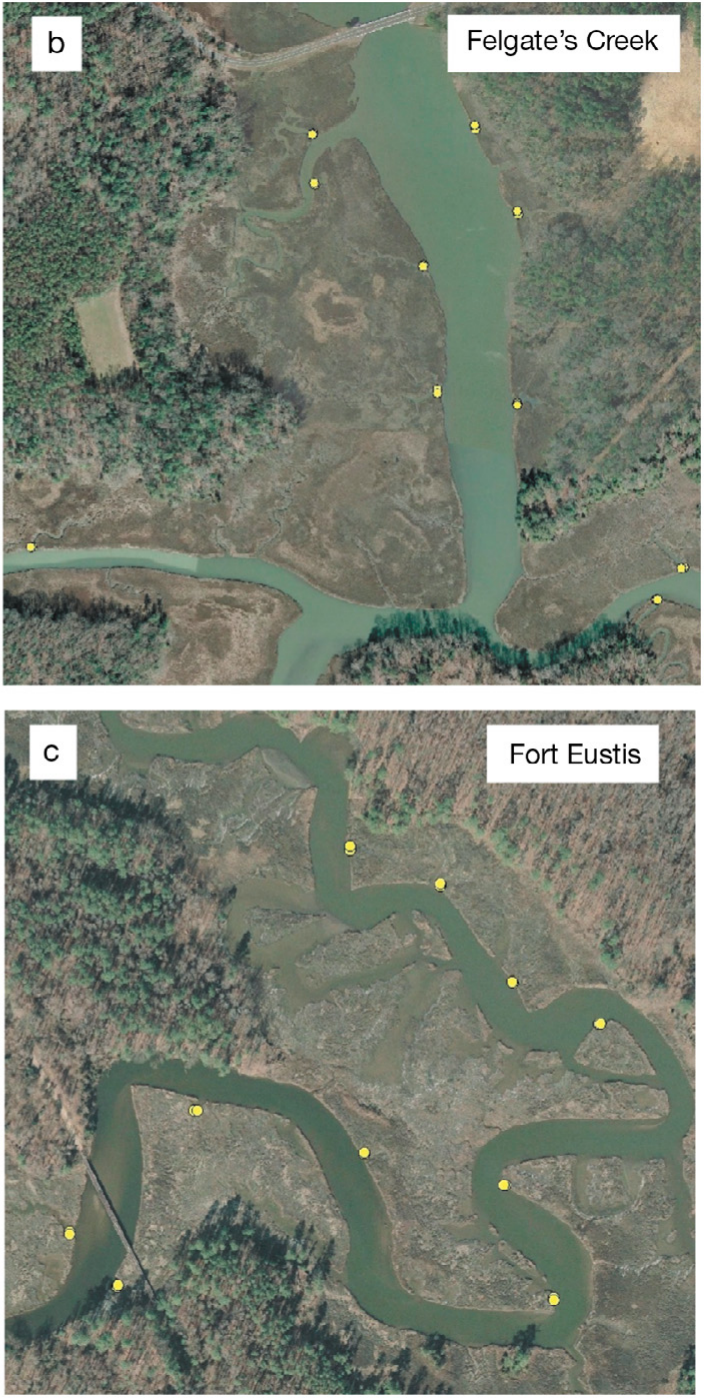


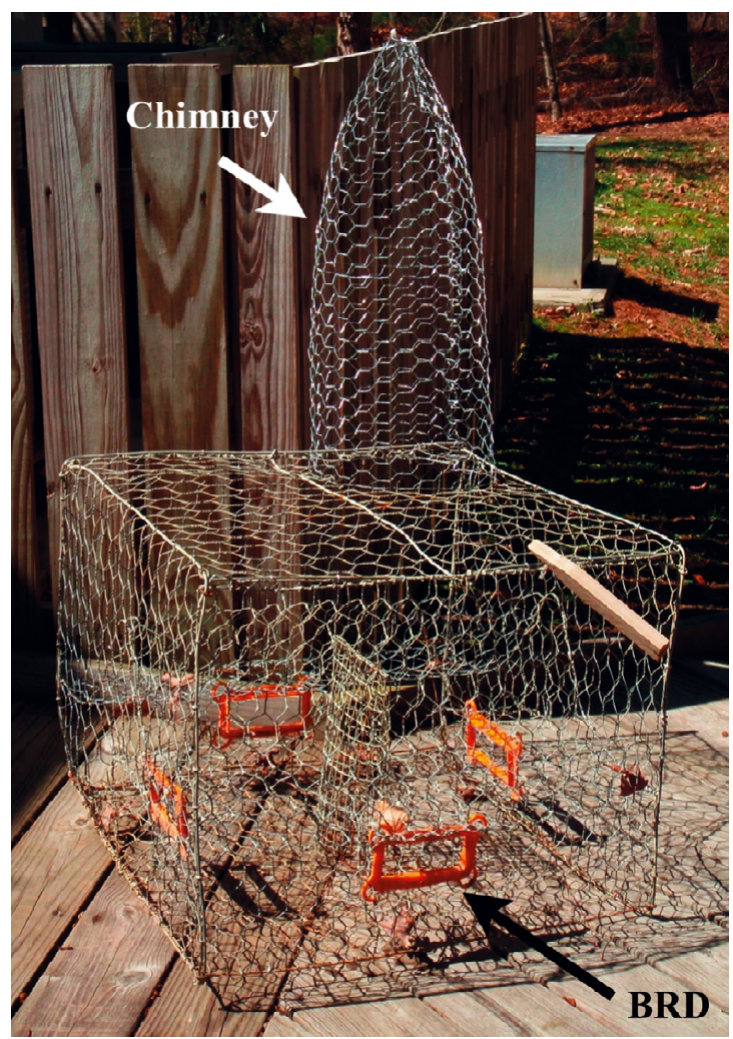

Fig. 2. Crab trap with chimney and bycatch reduction devices (BRD)

crabs per trap were recorded at both sites. Traps were not fitted with cull rings. Carapace width was measured using field calipers and the sex of each crab was recorded. Carapace width (CW) was converted to biomass using the following equations (Smith \& Chang 2007):

$$
\begin{aligned}
\text { Biomass }_{\text {female }} & =0.000355 \cdot \mathrm{CW}^{2.571} \\
\text { Biomass }_{\text {male }} & =0.00027 \cdot \mathrm{CW}^{2.662}
\end{aligned}
$$

Terrapins trapped in crab traps were sampled and released continuously throughout the summer. The total number of terrapins per trap was recorded along with sex, age, and mass (to the nearest $5 \mathrm{~g}$ ). Measurements, to the nearest $\mathrm{mm}$, were recorded for carapace length and width, plastron length and width, and shell depth of each terrapin.

Crab-trap modifications. Aside from BRDs, crab traps were modified to eliminate terrapin mortality by cutting a hole in the top of each trap and securing a closed 'chimney' of chicken wire extending $60 \mathrm{~cm}$ above the hole (Fig. 2). The chimney allowed captured terrapins to swim up and breathe during high tide but kept them from escaping. Also, $2 \mathrm{~m}$ wooden stakes were driven into the mud, and chimneys were tied to the stakes to help prevent the traps from tipping over during times of high wave action or storms. Modifications for terrapin survival were assumed to have no effect on the crab catch since no trap was ever filled to capacity. Any error associated with the modifications should have affected non-BRD traps and BRD traps similarly.

Hypothesis testing and models. All data were analyzed using the information-theoretic (I-T) approach of maximum-likelihood multi-model comparisons (Burnham \& Anderson 2002, Anderson 2008). For terrapins in Felgate's Creek, we hypothesized that the total number of terrapins caught per trap would be lower in BRD traps, with a possible Date effect; the BRD $\times$ Date interaction was also tested, though the effect was hypothesized to be negligible.

For crab catch, we tested the effects of BRD, Site, and Date on total number of crabs, number of legal-size crabs, number of sublegal-size crabs, size of total crabs, size of legal-size crabs, size of sublegal-size crabs, biomass of total crabs, biomass of legal-size crabs, and biomass of sublegal-size crabs. For each of the abundance and biomass response variables, we used the difference in abundance and biomass between normal traps and traps with BRDs on a per trap per day basis. We compared 4 possible models considering each of the main effects independently and possible interaction effects (Table 1). For each of the size response variables, we examined the average carapace width of each crab captured in a standard trap

Table 1. Models tested for crab number and biomass analyses. $\alpha$ : bycatch reduction device (BRD effect) $\beta_{1}$ to $\beta_{3}$ : parameters representing coefficients for independent variables, $x_{1}$ : Date effect, $x_{2}$ : Site effect, e: error

\begin{tabular}{|ll|}
\hline Model & Equation \\
\hline$g_{1}$ & $y=\alpha+\beta_{1} x_{1}+e$ \\
$g_{2}$ & $y=\alpha+\beta_{2} x_{2}+e$ \\
$g_{3}$ & $y=\alpha+\beta_{1} X_{1}+\beta_{2} X_{2}+e$ \\
$g_{4}$ & $y=\alpha+\beta_{1} x_{1}+\beta_{2} X_{2}+\beta_{3} x_{1} X_{2}+e$ \\
\hline
\end{tabular}

Table 2. Models tested for each of 3 crab-size analyses. $\alpha$ : intercept, $\beta_{1}$ to $\beta_{7}$ : coefficients for independent variables, $x_{1}$ : Date effect, $x_{2}$ : Site effect, $x_{3}$ : BRD effect, e: error

\begin{tabular}{|ll|}
\hline Model & Equation \\
\hline$g_{1}$ & $y=\alpha+\beta_{1} x_{1}+e$ \\
$g_{2}$ & $y=\alpha+\beta_{2} x_{2}+e$ \\
$g_{3}$ & $y=\alpha+\beta_{3} x_{3}+e$ \\
$g_{4}$ & $y=\alpha+\beta_{1} x_{1}+\beta_{2} x_{2}+e$ \\
$g_{5}$ & $y=\alpha+\beta_{1} x_{1}+\beta_{2} x_{2}+\beta_{3} x_{3}+e$ \\
$g_{6}$ & $y=\alpha+\beta_{1} x_{1}+\beta_{2} x_{2}+\beta_{3} x_{3}+\beta_{4} x_{1} x_{2}+e$ \\
$g_{7}$ & $y=\alpha+\beta_{2} x_{2}+\beta_{3} x_{3}+\beta_{5} x_{2} x_{3}+e$ \\
$g_{8}$ & $y=\alpha+\beta_{1} x_{1}+\beta_{2} x_{2}+\beta_{3} x_{3}+\beta_{4} x_{1} x_{2}+\beta_{5} x_{2} x_{3}+$ \\
& $\beta_{6} x_{1} x_{3}+\beta_{7} x_{1} x_{2} x_{3}+e$ \\
\hline
\end{tabular}


and a trap with BRDs by comparing 8 possible models (Table 2). Akaike's information criterion (AIC) values and parameter estimates were obtained using the generalized linear model (GLM) function in the R statistics package (www.rproject.org). For analyses involving the total number of terrapins or crabs, the Poisson option was used with the GLM analysis because of the low numbers per trap.

\section{RESULTS}

\section{Terrapin bycatch}

In total, 48 terrapins were captured over 23 trapping days. Of these, 46 were caught in non-BRD traps, and 2 in BRD traps. The mean catch was 0.20 terrapins trap $^{-1} \mathrm{~d}^{-1}$ in non-BRD traps and 0.01 terrapins trap ${ }^{-1} \mathrm{~d}^{-1}$ in BRD traps (Fig. 3). Mean shell depth of terrapins captured in non-BRD traps was $5.1 \mathrm{~cm}$, and the smallest terrapin captured in non-BRD traps had a shell depth of $4.3 \mathrm{~cm}$. The 2 terrapins captured in BRD traps had a shell depth of $4.1 \mathrm{~cm}$. Since only 2 terrapins were

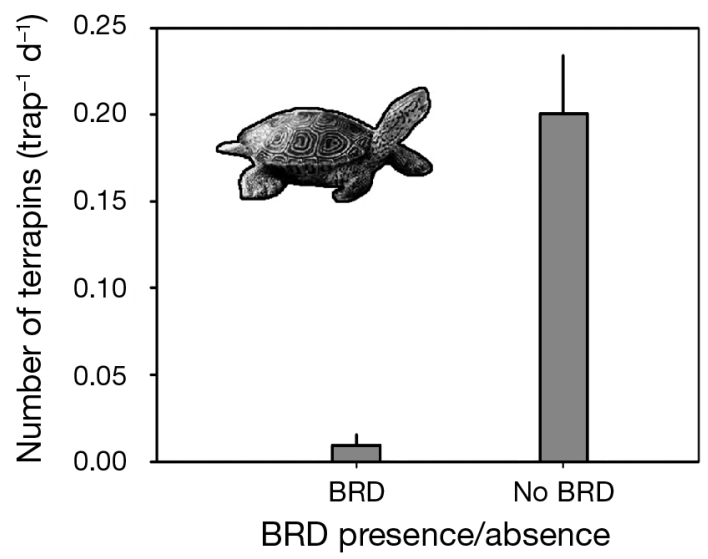

Fig. 3. Malaclemys terrapin. Average number of terrapins captured per trap per day in traps with and without bycatch reduction devices (BRDs). Error bars represent 1 SE. Traps with BRDs captured 2.9 crabs trap ${ }^{-1} \mathrm{~d}^{-1}$ while traps without BRDs captured 2.4 crabs trap ${ }^{-1} \mathrm{~d}^{-1}$ captured in BRD traps, which placed $100 \%$ of the data on only 2 of 23 dates, the BRD $\times$ Date interaction model was eliminated from the analysis. The model including the effects of BRD and Date was the most probable model with a weighted probability of 0.986 (Table 3 ). However, the Date effect was trivial, such that the BRD effect was the only significant effect.

\section{Crab catch}

\section{Abundance}

Over the 4 crab-trapping intervals we captured 348 blue crabs, with 137 caught at Fort Eustis and 211 caught at Felgate's Creek. In all analyses, Site was the only factor that had a noticeable effect, with crabs being more abundant at Felgate's Creek. For the total number and the number of legal-size crabs (legal number), the Site effect model $\left(g_{2}\right)$ had the greatest weighted probability and was used to estimate the BRD effect. For the number of sublegal-size crabs (sublegal number), both the Date effect model and the Site effect model had the highest probabilities but neither was a strong candidate for best model because of the low effect sizes and high variances (Table 4). Therefore, for abundance of sublegal-size crabs, a BRD effect was considered the most probable, though the estimated BRD effect was very small and not reliable due to the relatively high variance.

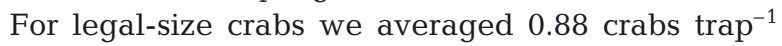
$\mathrm{d}^{-1}$ in traps without BRDs and 0.94 crabs trap ${ }^{-1} \mathrm{~d}^{-1}$ with BRDs (Fig. 4a), attesting to the small effect of BRDs on crab catch. For sublegal-size crabs, the averages were 1.19 crabs trap ${ }^{-1} \mathrm{~d}^{-1}$ in traps without BRDs and 1.31 crabs trap ${ }^{-1} \mathrm{~d}^{-1}$ with BRDs (Fig. 4b).

\section{Biomass}

Site had the strongest effect in all analyses. For total biomass and the biomass of legal-size crabs (legal biomass) the Site effect model $\left(g_{2}\right)$ was the

Table 3. Akaike's information criterion (AIC) values, deltas, and model weights as well as intercept and parameter estimates from all models for terrapin Malaclemys terrapin captures. Parameter estimates from the best model and the greatest model weight are in bold; $\alpha$ : intercept, $\beta_{1}$ and $\beta_{2}$ : parameters representing the coefficients for each independent variable. See

Tables $1 \& 2$ for details on models and parameters (mean $\pm \mathrm{SE}$ ). AIC $_{c}$ : corrected AIC, na: no data available

\begin{tabular}{|c|c|c|c|c|c|c|c|}
\hline Model & AIC & $\mathrm{AIC}_{\mathrm{c}}$ & $\Delta \mathrm{AIC}_{\mathrm{c}}$ & $\begin{array}{c}\text { Model } \\
\text { weight }\end{array}$ & \multicolumn{2}{|c|}{ - Parameter estimates } & $\beta_{2}$ \\
\hline$g_{1}$ & 320.96 & 321.01 & 47.88 & 0.00 & $-1.665 \pm 0.215$ & $-0.027 \pm 0.009$ & na \\
\hline$g_{2}$ & 281.72 & 281.77 & 8.64 & 0.013 & $-1.609 \pm 0.147$ & na & $-3.136 \pm 0.722$ \\
\hline$g_{3}$ & 273.04 & 273.13 & 0.00 & 0.99 & $-1.014 \pm 0.217$ & $-0.027 \pm 0.009$ & $-3.136 \pm 0.722$ \\
\hline
\end{tabular}


Table 4. Weighted probabilities for all models tested in the abundance and biomass analyses of blue crab Callinectes sapidus catch. Greatest model probabilities are in bold. Parameter estimates (mean \pm SE) from Model $g_{2}$ for number and biomass of legalsize (legal number, legal biomass) and sublegal-size (sublegal number, sublegal biomass) crabs, and from Model $\mathrm{g}_{3}$ for sublegal biomass. See Tables 1 \& 2 for details on models and parameters. BRD: bycatch reduction device; nd: not determined

\begin{tabular}{|c|c|c|c|c|c|c|}
\hline \multirow[t]{2}{*}{ Analysis } & \multicolumn{4}{|c|}{ Weighted probability } & \multicolumn{2}{|c|}{ Parameter estimates } \\
\hline & $\begin{array}{c}\mathrm{g}_{1} \\
\text { Date }(D)\end{array}$ & $\begin{array}{c}\mathrm{g}_{2} \\
\text { Site }(S)\end{array}$ & $\begin{array}{c}g_{3} \\
D+S\end{array}$ & $\stackrel{\mathrm{g}_{4}}{D+S+D \times S}$ & $\begin{array}{c}\alpha \\
\mathrm{BRD}\end{array}$ & $\begin{array}{c}\beta_{2} \\
\text { Site }\end{array}$ \\
\hline Total number & 0.073 & 0.594 & 0.239 & 0.094 & nd & nd \\
\hline Legal number & 0.199 & 0.501 & 0.222 & 0.079 & $0.300 \pm 0.240$ & $-0.525 \pm 0.339$ \\
\hline Sublegal number & 0.418 & 0.398 & 0.138 & 0.046 & $-0.350 \pm 0.234$ & $0.050 \pm 0.334$ \\
\hline Total biomass & 0.115 & 0.515 & 0.280 & 0.090 & nd & nd \\
\hline Legal biomass & 0.115 & 0.515 & 0.280 & 0.090 & $55.26 \pm 28.90$ & $-80.10 \pm 40.87$ \\
\hline Sublegal biomass & 0.114 & 0.188 & 0.457 & 0.241 & $12.60 \pm 31.75$ & $-35.42 \pm 30.59$ \\
\hline
\end{tabular}

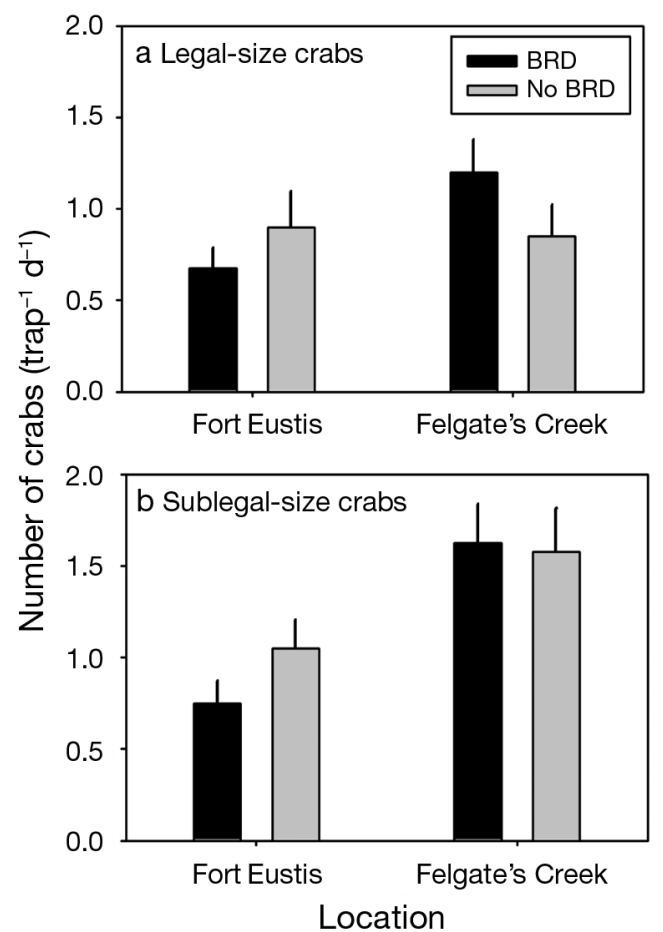

Fig. 4. Callinectes sapidus. Average number of (a) legal-size and (b) sublegal-size blue crabs caught at each site by trap type. BRD: bycatch reduction device. Error bars represent $1 \mathrm{SE}$

best. For the biomass of the sublegal-size crabs (sublegal biomass), the Site and Date effect model $\left(g_{3}\right)$ was the best (Table 4). Crabs were heavier at Fort Eustis than at Felgate's Creek. Legal-size crabs averaged $112 \mathrm{~g}$ at Felgate's Creek and $134 \mathrm{~g}$ at Fort Eustis. Crabs caught in BRD traps were 5 to $6.5 \mathrm{~g}$ heavier than crabs caught in non-BRD traps (Fig. 5a). For legal biomass, BRD traps caught $55 \mathrm{~g}_{\text {trap }}^{-1} \mathrm{~d}^{-1}$ more than non-BRD traps (Table 4). Sublegal-size crabs were also heavier in traps with BRDs than in traps without BRDs by 2.5 to $3.0 \mathrm{~g}$ (Fig. 5b). For sublegal biomass, BRD traps caught $13 \mathrm{~g} \mathrm{trap}^{-1} \mathrm{~d}^{-1}$ more than non-BRD traps (Table 4).

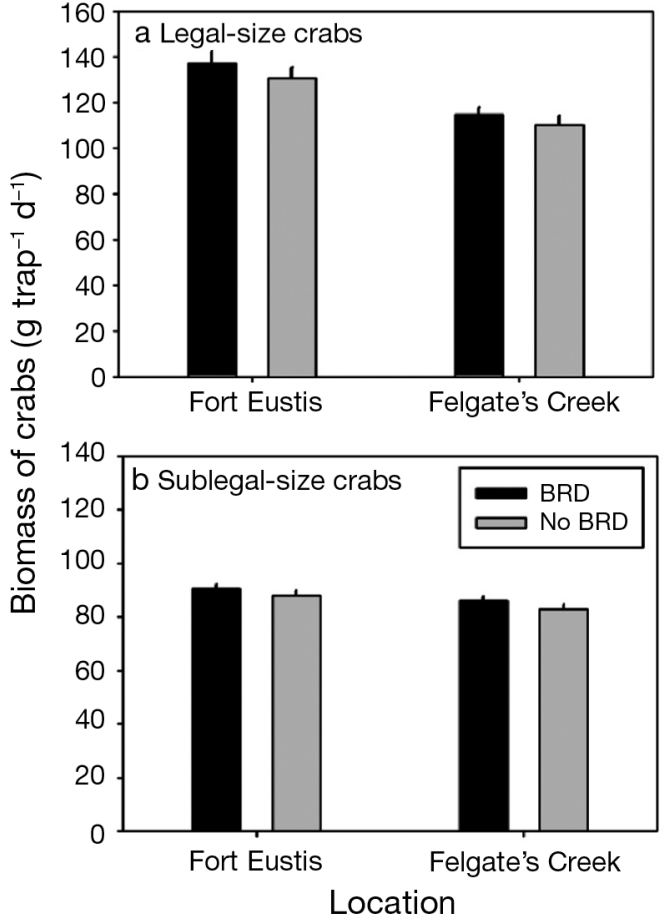

Fig. 5. Callinectes sapidus. Average biomass of (a) legal-size and (b) sublegal-size blue crabs caught at each site by trap type. BRD: bycatch reduction device. Error bars represent $1 \mathrm{SE}$

Size

In all analyses, Site had the greatest effect, Date had no effect, and BRD had a small effect compared to Site. For total and sublegal size, the model with the effects of Site, Date, and BRD $\left(\mathrm{g}_{5}\right)$ was the most likely model. For legal size, the model with the effects of Site and Date $\left(g_{4}\right)$ had the highest probability (Table 5), but parameter estimates changed only slightly from $g_{4}$ to $g_{5}$, so $g_{5}$ was used to obtain the BRD effect estimate. Site had a non-trivial effect for all size estimates, with Fort Eustis having larger crabs. Legal-size crabs averaged about $130 \mathrm{~mm}$ in carapace width at Felgate's Creek and 


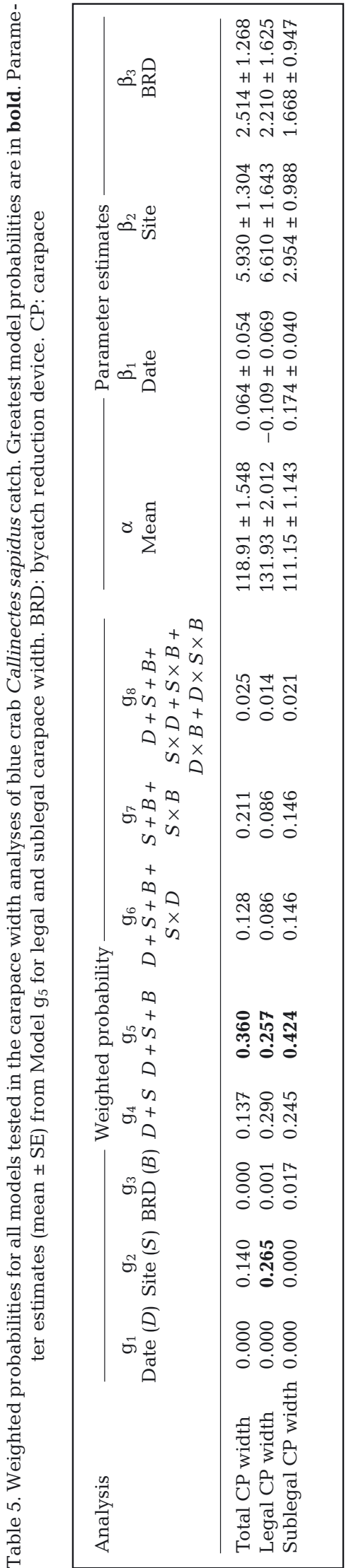

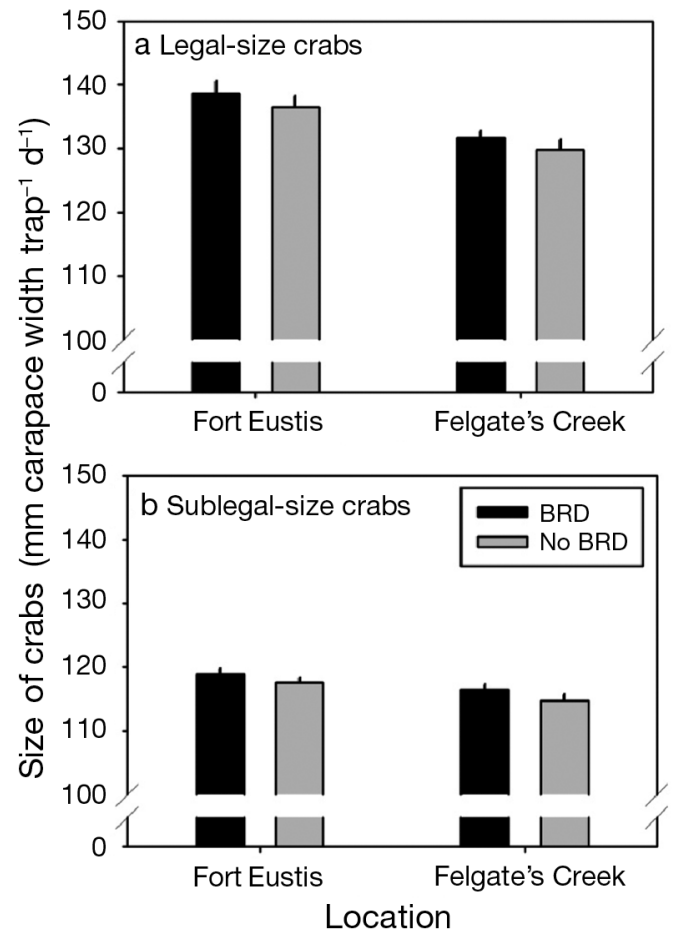

Fig. 6. Callinectes sapidus. Average carapace width of (a) legalsize and (b) sublegal-size blue crabs caught at each site by trap type. BRD: bycatch reduction device. Error bars represent $1 \mathrm{SE}$

$137 \mathrm{~mm}$ at Fort Eustis (Fig. 6a). Legal-size crabs caught in traps with BRDs were on average $2.0 \mathrm{~mm}$ larger in carapace width than crabs caught in traps without BRDs. This was consistent with the model estimate for the BRD effect of a $2.2 \mathrm{~mm}$ increase in carapace width (Table 5). Sublegal-size crabs caught in traps with BRDs were on average 1.5 to $2.0 \mathrm{~mm}$ larger in carapace width than crabs caught in traps without BRDs (Fig. 6b). This, too, was consistent with the model-estimated BRD effect of a $1.7 \mathrm{~mm}$ increase in carapace width (Table 5).

\section{DISCUSSION}

BRDs diminished terrapin bycatch in crab traps by $95.7 \%$. Using the Schnabel mark-recapture method (Krebs 1989), we estimated the terrapin population to be 167 terrapins (95\% CI: 113 to 299 terrapins). The 46 terrapins captured in traps without BRDs represented $27.5 \%$ of the estimated population at Felgate's Creek. This potential mortality rate could not be sustained by diamondback terrapin due to its K-selected life-history traits (Gibbons et al. 2001), including a long lifespan, late sexual maturity, and low fecundity. In contrast, the 2 terrapins captured in BRD traps represented only $0.6 \%$ of the estimated population, a loss that should be sustainable. 
Contrary to the substantial effect on terrapins, BRDs had little to no effect on crab catch. Traps with BRDs had slight increases in the number, size, and biomass of both legal-size and sublegal-size crabs caught. However, these increases were so marginal that the overall effect of BRDs on the crab catch was considered negligible.

The collective findings of the present study and previous studies (Wood 1997, Roosenburg \& Green 2000, Butler \& Heinrich 2007) support the contention that mortality of diamondback terrapins in crab traps can be dramatically reduced when traps are fitted with BRDs, while maintaining fishery catches of blue crab. In coastal marsh habitats and seaside lagoons of the northwestern Atlantic, Wood (1997) tested 3 types of BRDs, with the $4.5 \times 10 \mathrm{~cm}$ BRD the closest in size to that used in the present study. Similarly to our study, traps without BRDs caught 0.17 terrapins and 1.67 crabs trap ${ }^{-1} \mathrm{~d}^{-1}$, whereas traps with BRDs captured no terrapins and 0.80 crabs $\operatorname{trap}^{-1} \mathrm{~d}^{-1}$. In upper Chesapeake Bay, Roosenburg \& Green (2000) saw a decrease in the number of crabs trapped per day when they used $4 \times 10 \mathrm{~cm}$ BRDs and $5 \times 10 \mathrm{~cm}$ BRDs on normal crab traps and specially constructed 'tall' crab traps that prevented terrapins from drowning. However, unlike in the present study, when using the same-sized $4.5 \times 12 \mathrm{~cm}$ BRDs they counted a crab catch that was significantly higher $(2.69$ crabs $\operatorname{trap}^{-1} \mathrm{~d}^{-1}$ ) relative to catch in normal-sized non-BRD traps $\left(2.55\right.$ crabs trap $\left.{ }^{-1} \mathrm{~d}^{-1}\right)$, although crab size did not differ between BRD and non-BRD traps. In their specially constructed tall pots, crab catch was 1.0 crabs trap ${ }^{-1} \mathrm{~d}^{-1}$ in non-BRD pots and increased to 1.14 crabs trap ${ }^{-1} \mathrm{~d}^{-1}$ in BRD pots with no difference in size of crabs between pots. In contrast to the present study, they found that all sizes of BRDs reduced terrapin bycatch (Roosenburg \& Green 2000); the $4 \times$ $10 \mathrm{~cm}$ BRD completely eliminated bycatch, the $4.5 \times$ $12 \mathrm{~cm}$ BRD reduced bycatch by $62 \%$, and the $5 \times$ $10 \mathrm{~cm}$ BRD reduced bycatch by $53 \%$. At 8 sites along coastal habitats of the Gulf of Mexico and Atlantic Ocean in Florida (USA), Butler \& Heinrich (2007) compared traps fitted with a $4.5 \times 12 \mathrm{~cm}$ BRD, samesized as in the present study, and without a BRD. Their findings were very similar to those of the present study; traps without BRDs captured 37 terrapins, whereas traps with BRDs caught only 4 terrapins, 1 of which was due to BRD failure. Additionally, crab catch in traps with BRDs was higher than that in non-BRD traps at 3 sites, lower at 2 sites, and similar at 3 sites, resulting in an overall increase in crab catch in BRD traps. Since height of a BRD affects the ability of terrapins to enter a trap and width of a BRD affects the ability of a crab to enter a trap, the $4.5 \times$ $12 \mathrm{~cm}$ BRD appears to be a good compromise between reducing bycatch and not adversely affecting the crab catch.

As in other studies, traps with BRDs also reduced other bycatch in our experiments. Whereas the only bycatch in BRD traps consisted of 2 small terrapins, non-BRD traps captured several species of fish, a Virginia rail, a muskrat, a nutria, and several mud and snapping turtles. In Wood's (1997) study, which was conducted in deeper waters, bycatch comprised spider crabs, conchs, and several species of fish. BRDs therefore also have a direct benefit to wildlife, and not just for diamondback terrapin. Moreover, individual BRDs are inexpensive (US $\$ 0.42$ per BRD) and simple to attach to the entrances of crab traps, such that there are no obvious economic, environmental, or physical disadvantages to their use.

We therefore recommend the use of BRDs on all crab traps placed in diamondback terrapin habitat of the North American coastline, particularly for crab traps in the shallow waters fringing coastal marshes, estuaries, and lagoons. Specifically, we recommend the immediate implementation of BRDs on all recreational blue-crab traps throughout US waters, and serious consideration of implementation of BRDs in commercial traps deployed in shallow waters $(<2 \mathrm{~m}$ water depth). When BRDs were used in shallowwater recreational crab traps, crab catch was not affected. Studies in New Jersey, Maryland, and Florida reported similar findings when shallow-water commercial trapping techniques were employed. Our findings, combined with those of other studies, suggest that shallow-water commercial catch will also not be affected. Conversely, BRDs may not be necessary for crab traps set in deeper waters where terrapins are scarce. Consequently, the selective use of BRDs in blue-crab traps represents an excellent example of ecosystem-based fishery management whereby the goals of marine conservation and fishery harvest can be met simultaneously.

Acknowledgements. We thank the following individuals and organizations for logistical support: The Chesapeake Program Cooperative Ecosystems Studies Unit; J. Pulver, C. Wilson, and C. Neill, US Department of Defense/Navy Chesapeake Bay Program, Navy Region Mid-Atlantic Environmental Unit; and T. Christensen and J. Dolan, Environmental and Natural Resources Division, US Army Garrison Fort Eustis. Funding for the project was provided by National Oceanic and Atmospheric Administration (NOAA) award NA08NOS4200272 to M.A.R., National Science Foundation (NSF) grant DEB0725453 to R.M.C., an Environmental Science and Policy (ENSP) undergraduate research award from the Mellon Foundation to B.M.B., and a NOAA Chesapeake Bay Office award through the Blue Crab Advanced Research Consortium to R.N.L. We also thank A. Morris, C. Dolph, and M. Schrack for field assistance. 


\section{LITERATURE CITED}

Anderson DR (2008) Model based inference in the life sciences. A primer on evidence. Springer, New York, NY

Bishop JM (1983) Incidental capture of diamondback terrapin by crab pots. Estuaries 6:426-430

Burnham KP, Anderson DR (2002) Model selection and multimodel inference. A practical information theoretic approach. Springer, New York, NY

Butler JA, Heinrich GL (2007) The effectiveness of bycatch reduction devices on crab pots at reducing capture and mortality of diamondback terrapins (Malaclemys terrapin) in Florida. Estuar Coasts 30:179-185

Butler JA, Heinrich GL, Seigel RA (2006) Third workshop on the ecology, status, and conservation of diamondback terrapins (Malaclemys terrapin): results and recommendations. Chelonian Conserv Biol 5:331-334

Cecala KK, Gibbons JW, Dorcas ME (2008) Ecological effects of major injuries in diamondback terrapins: implications for conservation and management. Aquat Conserv Mar Freshw Ecosyst 19:421-427

Clark WS (1982) Turtles as a food source of nesting bald eagles in the Chesapeake Bay region. J Field Ornithol 53: 49-55

Coker RE (1906) The natural history and cultivation of the diamondback terrapin with notes of other forms of turtles. North Carolina Geol Surv Bull 14:1-67

Coker RE (1920) The diamondback terrapin: past, present and future. Sci Mon 11:171-186

Conover DO, Munch SB (2002) Sustaining fisheries yields over evolutionary time scales. Science 297:94-96

Davenport J, Glasspool AF, Kitson L (2005) Occurrence of diamondback terrapins, Malaclemys terrapin, on Bermuda: native or introduced? Chelonian Conserv Biol 4:956-959

Dorcas ME, Willson JD, Gibbons JW (2007) Crab trapping causes population decline and demographic changes in diamondback terrapins over two decades. Biol Conserv 137:334-340

Ernst CH, Lovich JE, Barbour RW (1994) Turtles of the United States and Canada. The University Press of Kentucky, Lexington, $\mathrm{KY}$

Garber SD (1990) The ups and downs of the diamondback terrapin. Conservationist (NYSDEC) May-June:44-47

Gibbons JW, Lovich JE, Tucker AD, FitzSimmons NN, Greene JL (2001) Demographic and ecological factors affecting conservation and management of the diamondback terrapin (Malaclemys terrapin) in South Carolina. Chelonian Conserv Biol 4:66-74

Heppell SS, Heppell SA, Read AJ, Crowder LB (2004) Effects of fishing on long-lived marine organisms. In: Norse EA, Crowder LB (eds) Marine conservation biology: the science of maintaining the sea's biodiversity. Island Press, Washington, DC, p 211-231

Hildebrand SF (1932) Growth of diamond-back terrapins: size attained, sex ratio and longevity. Zoologica 9:231-238

Hoyle ME, Gibbons JW (2000) Use of a marked population of diamondback terrapins (Malaclemys terrapin) to determine impacts of recreational crab pots. Chelonian Conserv Biol 3:735-737

Jamieson GS, Grosholz ED, Armstrong DA, Elner RW (1998) Potential ecological implications from the introduction of

Editorial responsibility: Otto Kinne, Oldendorf/Luhe, Germany the European green crab, Carcinus maenas (Linneaus), to British Columbia, Canada and Washington, USA. J Nat Hist 32:1587-1598

Krebs CJ (1989) Ecological methodology. Harper Collins, New York, NY

> Lewison RL, Crowder LB, Read AJ, Freeman SA (2004) Understanding impacts of fisheries bycatch on marine megafauna. Trends Ecol Evol 19:598-604

> Lipcius RN, Stockhausen WT (2002) Concurrent decline of the spawning stock, recruitment, larval abundance, and size of the blue crab Callinectes sapidus in Chesapeake Bay. Mar Ecol Prog Ser 226:45-61

Parham JF, Outerbridge ME, Stuart BL, Wingate DB, Erienkeuser H, Papenfuss TJ (2008) Introduced delicacy or native species? A natural origin of Bermudian terrapins supported by fossil and genetic data. Biol Lett 4:216-219

Preikshot D, Pauly D (2004) Global fisheries and marine conservation: Is coexistence possible? In: Norse EA, Crowder LB (eds) Marine conservation biology: the science of maintaining the sea's biodiversity. Island Press, Washington, DC, p 185-197

Roosenburg WM (1991) The diamondback terrapin: population dynamics, habitat requirements and opportunities for conservation. New perspectives in the Chesapeake system: a research and management and partnership. Proceedings of a conference. Chesapeake Research Consortium Pub. No. 137. Chesapeake Research Consortium, Solomons, MD, p 237-234

> Roosenburg WM, Green JP (2000) Impact of a bycatch reduction device on diamondback terrapin and blue crab capture in crab pots. Ecol Appl 10:882-889

Roosenburg WM, Cresko W, Modesitte M, Robbins MB (1997) Diamondback terrapin (Malaclemys terrapin) mortality in crab pots. Conserv Biol 11:1166-1172

Roosenburg WM, Cover J, van Dijk PP (2008) Legal issues: legislative closure of the Maryland terrapin fishery: perspectives on a historical accomplishment. Turtle Tortoise Newsl 12:27-30

Silliman BR, Bertness MD (2002) A trophic cascade regulates salt marsh primary production. Proc Natl Acad Sci USA 99:10500-10506

Smith SG, Chang ES (2007) Molting and growth. In: Kennedy VS, Cronin LE (eds) The blue crab, Callinectes sapidus. Maryland Sea Grant, College Park, MD, p 197-245

Tucker AD, FitzSimmons NN, Gibbons JW (1995) Resource partitioning by the estuarine sea turtle Malaclemys terrapin: trophic, spatial, and temporal foraging constraints. Herpetologica 51:167-181

Tucker AD, Gibbons JW, Greene JL (2001) Estimates of adult survival and migration for diamondback terrapins: conservation insight from local extirpation within a metapopulation. Can J Zool 79:2199-2209

Wood RC (1997) The impact of commercial crab traps on northern diamondback terrapins, Malaclemys terrapin terrapin. In: Van Abbema J (ed) Proceedings: conservation, restoration, and management of tortoises and turtles-an international conference. New York Turtle and Tortoise Society, New York, NY, p 21-27

> Yearicks EF, Wood RC, Johnson WS (1981) Hibernation of the northern diamondback terrapin, Malaclemys terrapin terrapin. Estuaries 4:78-80

Submitted: July 9, 2009; Accepted: January 12, 2010

Proofs received from author(s): May 15, 2010 